\title{
CONTRADICTORY POLICIES The Museum Law in Regard to the Regulations for Contract Archaeology
}

\author{
Björn Magnusson Staaf
}

Lunds universitet

Institutionen för Kulturvetenskaper

Box 192, 22100 Lund, Sweden

bjorn.magnusson_staaf@kultur.lu.se

In 2017 a museum law was introduced in Sweden, the first of its kind in a Swedish context. The law says in its 8 th section that museum professionals must have an adequate competence and an advanced knowledge about the topics related to the subject field of the various museums. Section 8 also says that public museums shall contribute to research and the advancement of knowledge. This might appear as something selfevident, but the content of many laws is often seemingly obvious yet is still quite necessary to state. Developments that have taken place at Swedish museums during the last decade have also resulted in a drain of competence and expertise. This decline has of course also had consequences for the research and advancement of knowledge at museums, as well as for the quality of the pedagogical work. This decline of competence is particularly clear when it comes to the field of archaeology. It is my personal belief that the current museum law is a step in a new and better direction. Still, there are other legal regulations that more or less counteract the intentions of the new museum law, structures that to a large degree have caused a drain of archaeological competence at museums. 
Most visitors to museums still find archaeological collections and exhibitions interesting, and those who manage museums have nothing against archaeology. It is thus not a planned strategy on the part of the leaderships or boards of museums that has caused a drain of archaeological competence at many museums in Sweden. The most important reason for the current weak position of archaeology at Swedish museums is connected to developments within the field of contract archaeology that have taken place during the last two decades. Twenty years ago contract archaeology had a strong position at many Swedish museums. This is not the case any more.

Sometimes one can sense a touch of bitterness when talking to archaeologists working within the field of contract archaeology today. If one looks at how the conditions for contract archaeology have developed during the last fifteen years, this feeling is quite understandable. The academic quality of contract archaeology was once disputed. During the I990s the quality of research improved considerably, and became of a very high standard. The understanding of both prehistory and the medieval period has also radically transformed during the last decades thanks to the high scholarly ambitions in contract archaeology. However, this was not the only point of critique aimed at contract archaeology in the I990s. It was also questioned whether a wider audience, outside the circle of scholars, benefited from contract archaeology. Again, contract archaeology tried to answer these demands, and it has in a large number of cases also succeeded very well in doing so. There is today an impressive amount of quite extraordinary pedagogical projects that have been carried out within the framework of contract archaeology. The vast majority of these projects must be labelled as successful, from point of view of reaching new and heterogeneous audiences, developing new pedagogical methods, and achieving good results in conveying advanced and complex understandings of the past. Several of these projects were conducted within the frames of contract archaeology directly connected to museums. Yet, with a few exceptions it is very hard to find examples where these successful pedagogical projects have transformed museum practices on a more profound level. A reason for this is quite simply that the contract archaeology units at several museums have experienced redundancies, or have been shut down completely. The contract archaeology unit at Malmö Museums, for example, was one of the largest in the country twenty years ago. Today there is no contract archaeology unit at Malmö Museums, which still is one of the biggest regional museums in Sweden. The reason for this is that it has become more economically rational from a commercial point of view to conduct contract archaeology within organizations separate from museums. 
Contract archaeology in Sweden was a highly regulated practice until the late I990s. Each contract archaeology unit had its 'territory' for documentation and research. One can say that this system was closely connected to the national organization of regional museums that was introduced during the I970s in Sweden. During the late I990s these structures started to change. The primary reasons for this were two: one was that some building entrepreneurs found the cost of contract archaeology too high, another can be considered to be ideological. The ideals of New Public Management and New Liberalism had a breakthrough in politics and in public service in the I980s and I990s in Sweden. The general idea was that deregulation and a market-based economy would improve the quality of social services, increase efficiency and make it less costly. The implementation of New Public Management in Sweden has led to enhancements in several sectors of the public sphere, but not in all. It is highly debateable whether contract archaeology has had any real benefits at all from these structural changes.

One could argue that the quality of contract archaeology has become better with respect to the scholarly and pedagogical aspects, due to the changes in regulation. However, on a closer look it is clear that methodological and theoretical ambitions started to rise well before the structural transformations came about, for example with the excavations at Fosie that were directed by Nils Björhem and Ulf Säfvestad at Malmö Museums. It is also questionable whether the costs of the contract archaeology have become cheaper for the building entrepreneurs, which was the primary object of the deregulation. Seen from a wider perspective it might actually be that the cost efficiency of contract archaeology from a public social perspective has dwindled considerably instead. The cost of contract archaeology is still there, but the infrastructure for reaching a wider audience has become unstable. The development at the museums is a clear indicator of this.

The contract archaeology at museums was and is a fully self-financing undertaking. In other words, in the budgets of many museums archaeology is financed through other means than public funding, which normally is the most important source of income for Swedish museums. The old system where the contract archaeology units had their 'territories' gave a more stable ground for planning. Naturally, contract archaeology was sensitive to changes in economic cycles and shifts in building activities also in this system, but it guaranteed at least a form of continuity. It also ensured a presence of archaeological competence at the museums. The museum archaeologists were from this point self-financed, long before the ideas of New Public Management. The deregulation of contract archaeology disrupted the structures that had secured the pres- 
ence of archaeological competence at museums. It became more financially risky for museums to support contract archaeology when there no longer were any 'territories'. The risks of making an economic loss if the contract archaeology units didn't win the competitive bids for excavations became apparent. This was the reason to why the public culture management of the City of Malmö decided to shut down the contract archaeology at the Museums of Malmö. The partial deregulation of contract archaeology contributed to a lowering of the self-financing potential of museums.

The losses of income from contract archaeology which the museums suffered were not compensated by, for example, increases in public funding. The tougher conditions for contract archaeology at museums thus led in several cases to major redundancies in the archaeological staff in the 2000 s. It is the current structures of contract archaeology that are the primary cause of the drain of archaeological competence at least from the regional museums. It is not the alleged politicizing of museum practice that is sometimes claimed. These structures can partly be seen as obstructive to the ambitions of the new museum law and its practical implication, at least when it comes to the field of archaeological practice at museum. It is also a system that counteracts the intentions of the Culture Bill presented to the Swedish parliament in 2009. One of the aims presented in this bill is that the public cultural institutions of Sweden should strive for an increased level of self-financing.

It is now time, twenty years after the changes of regulation for contract archaeology, to make a thorough evaluation of what consequences they have had. It is of pivotal importance in this context to strengthen the archaeological competence at the Swedish museums, and to create new structures for pedagogical practices and research that guarantee continuity. It might seem very difficult and challenging once again to reform the regulations for contract archaeology. However, the system managed to change twenty years ago, therefore it must be possible to transform it again. Nor does it mean that a return to the conditions before the I990s is wanted. Yet, when looking at costs, it must be remembered that contract archaeology is not something that is done in the interest of the building entrepreneurs or real estate developers, it is done in the interest of the citizens. What is needed first and foremost is therefore a pragmatic public governance strategy with an aim of giving the citizens the best archaeological value possible in balance with reasonable financial costs. I am convinced that the museums have an important role to play in the development of such strategies. 